STONE CENTER ON SOCIO-ECONOMIC INEQUALITY

WORKING PAPER SERIES

No. 01

Real Urban Wage in an Agricultural Economy Without Landless Farmers:

Serbia, 1862-1910

Boško Mijatović

Branko Milanović

February 2020

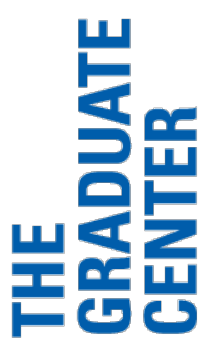


February 2020

Real urban wage in an agricultural economy without landless farmers:

Serbia, 1862-1910

Boško Mijatović and Branko Milanović ${ }^{1}$

\begin{abstract}
The paper presents the first estimate of the welfare ratio for Serbia using the 19 th and early $20^{\text {th }}$ century data on wages of skilled and unskilled workers (including the part paid in kind) and prices of goods that enter into "subsistence" and "respectability" consumption baskets. It finds a stagnation of unskilled wage, and a modest increase in skilled wage. The paper introduces several adjustment to conventional methodology in order to make it more relevant for predominantly agricultural societies.
\end{abstract}

\footnotetext{
${ }^{1}$ Respectively, Center for Liberal and Democratic Studies (CLDS), Belgrade, and Graduate Center, City University of New York, New York. We are grateful to Luka Mrkobrada for contributing to the data collection work. We thank the editor and three referees for very detailed and valuable comments, as well as Mihail Arandarenko,. Miloš Jagodić and Milan Zavadjil and the participants of a seminar held at CLDS in June 2018 where the first draft of the paper was presented. Corresponding author: bmilanovic@gc.cuny.edu.
} 


\section{Introduction and the objective of the study}

The paper presents first estimates of the real urban wage for the $19^{\text {th }}$ century and pre-World War I Serbia, following the work that has been done on historical real wages in a number of countries and using as a starting point the methodology developed by Robert Allen. The objective of real wage studies has been to assess living standards of the populations before national accounts became available. Since estimates of the real wage are practically non-existent for the $19^{\text {th }}$ century Balkans (see however Pamuk 2006) and since the economic structure of several countries, Serbia, Bulgaria and Greece, was similar (small peasant farms with almost no landless farmers and backward agricultural technology), the results can be used as an approximation of the real wage in the region, and by extension of its real income. Some demographic and social features of these economies diverge from the assumptions that are often in this type of stuidies based on Western experience. We therefore introduce several modifications to the methodology, explain their broader ratonale, and expect that they may be found useful for similar studies elsewhere.

We find the urban wage of unskilled workers to have exceeded the level ensuring bare subsistence of the family by approximately $50 \%$ on average over the period $1862-1910$. Its level, however, shows no increase: at the end of the period, it was almost exactly the same as in the beginning. The stagnation of unskilled real wage is found under a number of different assumptions regarding the size of household, the value of food and drinks provided by employers in natura to workmen, and the number of days worked annually. We believe that this result confirms absence of modern economic growth in Serbia in the second half of the $19^{\text {th }}$ century and all the way to the First World War, thus highlighting the economic divergence between South-East and Western Europe. Thus while the objectives of the paper are narrow and empirical, it provides one of the observations necessary for better understanding of European and global divergence of living standards during the $19^{\text {th }}$ century.

The structure of the paper is as follows. Section 2 gives an aperçu of economic and political situation in Serbia during the period under study. Section 3 presents a summary of key features of Allen's methodology and describes the data we use. In light of the specific social structure of Balkan countries, Section 4 introduces several methodological adjustments to Allen's methodology. Section 5 provides our results and discusses them in relation to contemporaneous economic and political developments in Serbia. It also includes a comparison with the results for selected other countries which can be seen as an external 
validation of our results. Section 6 concludes the paper highlighting some issues inherent in this type of work and giving some suggestions regarding future research.

\section{Structural features of Serbia's economy in the second half of the $19^{\text {th }}$ century}

One of the specific features of South-East European countries in the $19^{\text {th }}$ century was the prevalence of small-scale land holdings cultivated by peasant-owners. It is important to note that such countries had neither the features that have become traditionally associated with the development of capitalism in the West and especially in England (the ternary class division into landlords, tenant-farmers, and peasants) nor of East European countries that had landed nobility and until rather late in the $19^{\text {th }}$ century preserved the elements of serfdom or corvée labor (Russia, Poland, Hungary).

There are several important structural or long-term features of Serbia during the period under study. They are: (1) an overwhelmingly agricultural population, (2) land mostly owned by peasant, (3) communal (either extended family or kin-group) land holdings that were gradually replaced by clear private ownership of land, (4) modest human capital, (5) lack of agricultural credit, and (6) unclear property rights. We discuss them in turn.

Serbia was an agricultural economy with strong population growth, but not necessarily with a diminishing arable land-to-labor ratio, as argued by Palairet (1997) since the arable land sometimes increased at a faster rate than the population. ${ }^{2}$ Despite high infant mortality, the average annual population growth rate between 1880 and 1910 was 1.7 percent. $^{3}$ Between 80 and 90 percent of the labor force was employed in agriculture, the rest being divided between a very tiny manufacturing, handcrafts. some services (mainly commerce), and government administration (including the military). ${ }^{4}$ It was a relatively simple social structure where government officials represented the upper class. ${ }^{5}$ Even on the eve of the First World War, Serbia's exports consisted almost entirely of agricultural goods (livestock, cereals and fruits).

\footnotetext{
${ }^{2}$ For example, between 1900 and 1910, the cultivated land increased by 24 percent vs. 16 percent increase in population (data from the Statistical Yearbooks of the Kingdom of Serbia).

3 Statisticki Godisnjak Kraljevine Srbije (Statistical Yearbook of the Kingdom of Serbia) 1910.

${ }^{4}$ The share of the rural population in 1889 was estimated at 88 percent (see Dry̌avopis (State Statistics), vol. XI, 1889 , p. XIX).

${ }^{5}$ See Svetozar Marković, Srbija na istoku (Serbia in the East), Chapters VIII and IX.
} 
Serbian farmers almost to a man (it was a male-dominated society) owned their own land thanks to the extensive and egalitarian land reform that took place as the country gained independence from the Ottomans. Large Ottoman (Muslim) estates were taken over or bought and the land that was already tilled by (Christian) peasants became their formal property. The agrarian reform began in 1833 and by the time our data start (1862), it was completed. Farms were very small. ${ }^{6}$ As Figure 1, based on the agrarian census of 1897 shows, 55 percent of households owned farms smaller than 5 hectares. The average farm size was just over 7 hectares, and large properties (other than municipal or state land) were practically non-existent. The census reports only 86 farms, out of 300,000, with more than 100 hectares. There were almost no landless peasants. The inalienable homestead, introduced in stages from 1837 to 1873 , consisted of a building, three-and-half hectares of arable land, two oxen, five sheep or rams, and the essential agricultural implements. It could not be sold to pay off a private debt (and after some further legislation, not even to pay overdue taxes). ${ }^{7}$ It was a bulwark against rural poverty. So hunger was rare.

Figure 1. Distribution of households according to farm size, 1897

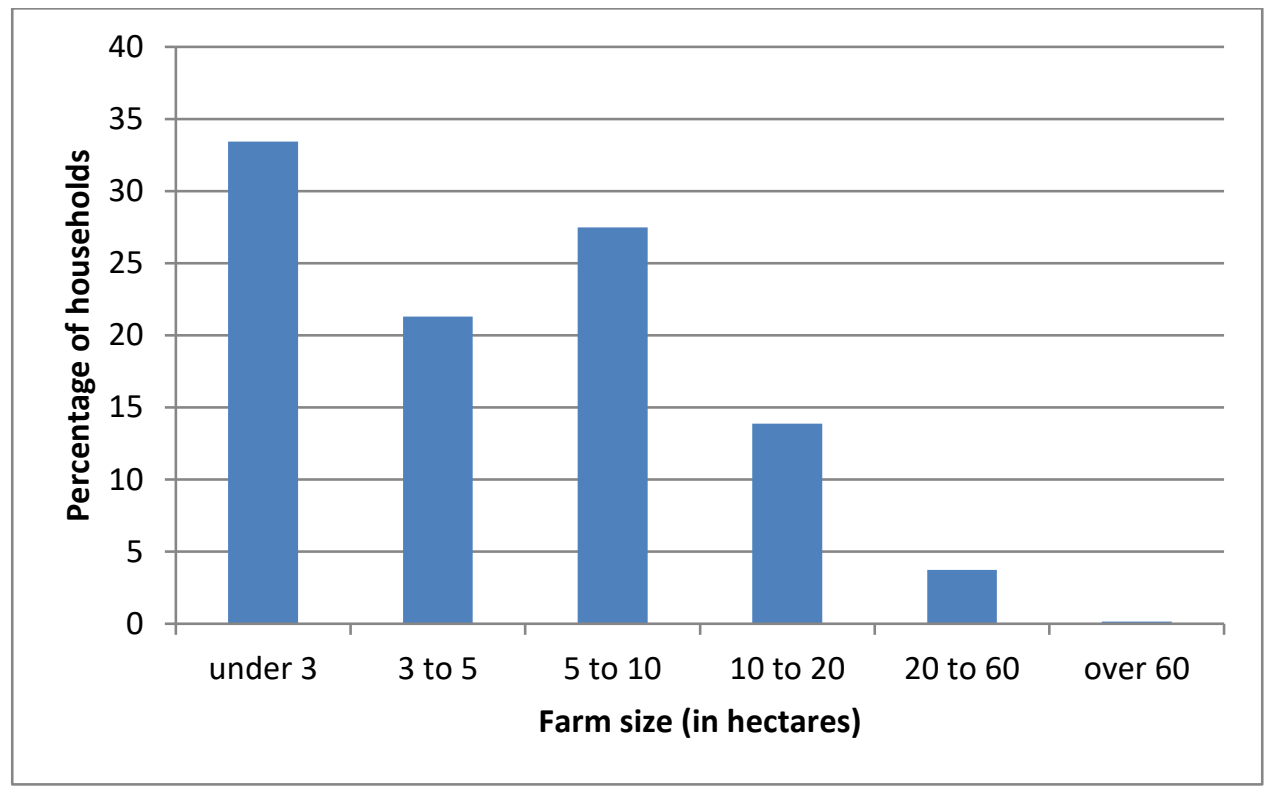

Source: Data from the 1897 Agrarian Census reported in Statistički Godišnjak (the Statistical Yearbooks of the Kingdom of Serbia) for 1900.

\footnotetext{
${ }^{6}$ The small size was not necessarily a limitation on the efficiency of production as such because with the technology then available to the farmers, it is doubtful that they could have cultivated much larger plots.

${ }^{7}$ Milorad Zebić, La Serbie agricole et sa democratie, Librairie Berger-Levrault, Paris, 1917, p. 37.
} 
The period studied here is also characterized by the gradual dissolution of the traditional multi-generational farmer households (zadruga) which were replaced by the more “modern” family landholdings. Since zadrugas typically produced most of the goods (food, wine, clothing) for own consumption and only infrequently engaged in exchange, their break-up also led to a greater marketization of production and to the emergence of the wage labor. ${ }^{8}$

Under the classical Arthur Lewis (1954) modernization scenario, the bulk of urban labor is provided by landless farmers who migrate to cities: their wages are fixed at the level of the best rural alternative (which is close to subsistence) and are sticky upward. In the case of Serbia, however, wage labor owned land and, in some cases, was still engaged in multigenerational households providing in natura for most of their needs. This had significant implications for farmers' willingness to supply labor at an urban open market. Unlike in a landless setting, where the potential wage earner has practically no choice, here for the farmer the opportunity cost of taking an urban job is the amount of net income he could make working on own land.

Low human capital is a long-lasting feature of the Serbian population of the nineteenth century. The Serbian population was largely illiterate at the time of independence: the literacy rate in 1830 was less than 5\%.' The first schools gradually appeared, but with few pupils and often unqualified teachers. In 1858, only about 12,000 pupils were trained, who would hardly have been able to write and do elementary calculations at the end of the studies. ${ }^{10}$ Expert knowledge, primarily regarding agriculture, was almost non-existent. Throughout the $19^{\text {th }}$ century, livestock breeding was done using primitive extensive grazing, no manure system, and with antiquated and low-productivity breeds. Farming was not more advanced: maintenance of soil's fertility (crop rotation, fertilizing, fallowing or the three-field

\footnotetext{
8 The Serbian zadruga is similar to the better known Russian obshcbina or mir. In both, several (in the Russian case, sometimes dozens) multi-generational peasant households held the land in common ownership. The land could not be alienated by individual members. They could leave zadruga but were then ostracized by the family, and could take with themselves only personal property. Note that zadruga's common land ownership should be distinguished from the "commons" used mostly for pasture which, like in England prior to the enclosures, were open to all farmers living in the area. The Serbian terms are very clear on that: there was zadruð̌na zemlja (zadruga-owned land) and opstinska zemlja ('association'- or 'municipality' owned land).

${ }^{9}$ See Momčilo Ilić, Pismenost u Srbiji u 19. veku (Literacy in Serbia in the 19 ${ }^{\text {th }}$ century), Belgrade, 2003, pp. 63-80.

${ }^{10}$ Ljubinka Trgovčević (1994, p.21).
} 
system) was applied slowly or not at all, while better tools (iron plough instead of wooden) also entered into use very slowly.

Such backward agriculture had difficulty increasing output and providing rising population with enough food, and in addition generating export surpluses. Yet some improvements did occur. Knowledge of agricultural techniques spread as literacy grew. Literacy reached the overall rate of 17 percent in 1900, while in the rural areas it was 12 percent. For men/boys older than six, however, rural literacy was 28 percent. ${ }^{11}$ In addition, the state set up various institutions whose aim was to improve agricultural techniques: secondary schools for the education of agricultural experts (two farming schools, one cattle breeding, one vineyard-orchard school); established an experimental farm in Topčider, near Belgrade; set up a cattle-breeding institute, created eight agricultural centers, fifty-five fruit and vineyard nurseries etc. ${ }^{12}$ All of this offered to the peasants more productive livestock breeds and types of crops and fruits.

During the nineteenth century, the Serbian state, often controlled by political parties that represented farmers' interests, undertook numerous measures to protect peasants from the risks brought about by capitalist economy. ${ }^{13}$ The goal was to preserve the small peasant estate and to create a society of "free" peasantry. ${ }^{14}$ There were several government measures that completely cut off peasantry from the regular financial markets: the ban on the sale of a part of one's property (the homestead) to pay off debts to private individuals, banks or the state and the prohibition of alienation of farms under 3.5 hectares; the statutory limitation of the interest rate to 12 percent per annum; ${ }^{15}$ and inability of the

\footnotetext{
${ }_{11}$ Calculated from Popis stanovnistva u Kraljevini Srbiji 31. decembra 1900, (Population Census of the Kingdom of Serbia on 31 December 1900), volume 2, Belgrade 1905.

12 Statistickei godišnjak Kraljevine Srbije za 1906 (Statistical Yearbook of the Kingdom of Serbia for 1906), vol. XI, 1908, pp. 261-267.

${ }^{13}$ Until 1888, all adult males who paid any amount of direct taxes had the right to vote. With the new constitution in 1888, a tax census of 15 dinars per year was introduced, which still meant that the franchise was over $80 \%$ of the adult male population. This was a very high percentage compared to the then advanced European countries (see Antonic, 2014). Not surprisingly, parties with populist and pro-peasant programs tended to win elections and to form government.

14 Boško Mijatović, "Zaštita seljaka od finansijskih rizika u nekadašnjoj Srbiji” ("Protection of peasants from financial risks in Serbia”), Glas SANU, Odeljenje društvenih nauka, vol. 27, 1995.

15 As a consequence, loans at usurious rates of up to 100 percent per year were not rare (see Marie-Janine Čalić, Socijalna istorija Srbije 1815-1941 (The Social History of Serbia, 1815-1941), Clio, Belgrade, 2004, p. 71).
} 
rural population to borrow by issuing promissory notes. Lack of credit hindered technological modernization (land improvement, purchase of new tools, quality improvement of cattle, use of more fertile and better quality plantings, etc.). Taken together these policies prevented the emergence of larger and more efficient farms although, on the positive side, they ensured that landlessness remained a marginal phenomenon. ${ }^{16}$

Compared with the West European experience of a century or century-and-half earlier, it seems clear that these policies prevented a faster capitalistic development of both agriculture and industry as well as faster urbanization. In 1910, the urbanization rate in Serbia was 13.2 percent. In Europe, only Russia and Finland were less urbanized (Marie Janine Čalić, 2004, p. 183). Many politicians and commentators remained strongly attached to the idea of an agriculture-based non-capitalist economy. The idea found support among the right-wing patriarchal politicians, among nationalist and left-wing parties that thought of zadrugas and peasant free-holdings as being a distinct Slavic, Orthodox and more "humane" organization of production, and even among early anarchists and Marxists who saw the communal forms of ownership as capable of providing a shortcut to socialism. ${ }^{17}$

The absence of a modern cadastral system also presented a problem. The Ottoman system based on simple issuance of title deeds remained unchanged although it was increasingly obsolete and unreliable. The boundaries of properties were not precisely determined and this led to innumerable court disputes. Peasants often illegally seized state or municipal land, striving afterwards to legalize such seizures. But their ownership rights remained for long controversial and farms, even when larger than 3.5 hectares, were taken out of circulation: they could neither be sold nor bought not could money be borrowed using the land as collateral. ${ }^{18}$

\footnotetext{
${ }^{16}$ Unable to sell the land they owned or to borrow against it, peasants did not want to leave it either. So they remained there, tied to a piece of land, in words of one contemporary (cited in Čalić, 2004, p. 41) "neither able to live nor to die". On the other hand, some economic historians (Vučo, 1955) estimate that the homestead law prevented the pauperization of between 10 to 15 percent of peasants.

17 Svetozar Marković, one of the earliest and most influential Serbian socialists, held this view, shared by the way, as regards Russia, by some Russian Marxists and indeed discussed by Marx in his famous 1881 letter to Vera Zasulich.

18 "Only a minority in the countryside... has title deeds for their possessions, and even then they are often incorrect and unreliable. Disputes over land are multiplying from year to year, and no one can stand in the way of enclosures of municipal meadows. Moreover, the state property is taken up abruptly, and it has in some ways created a state of lawlessness in the whole country ", Težak, 26 June 1894, p. 225.
} 


\section{The data and methodology}

As mentioned in the introduction, our approach essentially follows Allen's ${ }^{19}$ but on several issues, discussed in the next Section, departs from it due to the difference in the social and demographic structure of Serbia compared to what is typically assumed by Allen and economic historians who follow him. As is common in the literature, we calculate wages for two types of laborers: a construction worker and an "ordinary" unskilled worker, and use two baskets of goods: a "respectability basket" and a much more austere the "bare-bones" or subsistence basket. The "bare-bones" basket would ensure a mere survival and is based on nutritional norms. The baskets are "self-weighted": the weight of each good is given by the physical quantity of that good multiplied by its price. Assuming that the worker is the only member of a typical four-member household working outside home for a monetary wage, the nominal wage is compared to the baskets of goods (consumption) for all members of the household. That family basket is, again following the literature, equal to three adult baskets-under the assumption that the needs of children (in terms of food and calories) are $1 / 2$ of the those of the adults. Finally, 5 percent is added on top of that as an estimate of housing costs. The wage divided with the value of such basket is called the "welfare ratio" with 1 (when using the "bare bones" basket) indicating that the wage earned by a worker was just sufficient to keep the family of four members at the level of physiological minimum. All higher ratios, of course, provided more than that.

Calculations following this approach have been conducted for a number of West European cities (Allen 2003), but were later expanded to the United States (Lindert and Williamson, 2011), and in several influential papers by Şevket Pamuk (Özmucur and Pamuk, 2002; Pamuk 2006 and 2007) to the area controlled by the Ottoman Empire, including South-East Europe, today's Turkey, and the Middle East. More recently, the welfare ratios have also been estimated for the Habsburg Empire (Cvrček 2013), China’s Yangtze delta in the $19^{\text {th }}$ century (Li and van Zanden, 2012; Allen, Bassino, Ma, Moll-Murata and van Zanden, 2011), the British-ruled India (Allen, 2007; Broadberry and Gupta, 2006), Mexico (Challu and Gomez-Galvariatto 2015), the Dutch-controlled Java (de Zwart and Van Zanden, 2015), the pre-Meiji Japan (Bassino and Ma, 2005) and Tsarist Russia (Allen and

\footnotetext{
${ }^{19}$ For an early formulation, see Robert C. Allen, "The Great Divergence in European Wages and Prices from the Middle Ages to the First World War", Explorations in Economic History, October 2001.
} 
Khaustova, 2017). This work has informed the discussion about the Great Divergence between Europe and Asia, its timing, and the reasons why the Industrial Revolution has taken place in Northern Europe and not in Eastern China. ${ }^{20}$

How can Serbian data be fitted into what is required by Allen's methodology? For our purposes, the important thing is that statistical monitoring of economic and other phenomena started in 1862, when the Ministry of Finance's economic department was ordered to begin collection and publication of regular statistics. The precise method of data collection was prescribed: members of the local courts were ordered by the Announcement of June 27, 1862, No. 791 to record the average prices of products and wages in their localities. ${ }^{21}$ The reported prices had to be based on the actual prices observed in the sale and purchase of goods (and not on estimates); they had to be related to goods of average quality, and to be recorded once a week when the market is at its peak; monthly prices were derived from the weekly. ${ }^{22}$ The Ministry of Finance then calculated average monthly and annual prices for Serbia as a whole as the unweighted average of reported local prices and wages and published them in statistical yearbooks.

In the beginning, in 1862, prices of 48 products and three types of wages were recorded, while at the end of our period in 1910, there were 94 products and four types of wages. Annual wages were reported for three or four types of workers (the number varies between the years). ${ }^{23}$ They are: "ordinary worker" (običan radnik), digger, mower, and construction worker. For the unskilled worker, we use the reported wage of an "ordinary worker" which is practically indistinguishable from that of a digger. For skilled worker, we use the wage of a construction worker.

After the 1876-78 war with the Ottoman Empire, Serbia expanded territorially to the southeast and in 1880 the original list of 21 towns was enlarged by five more. The

20 The approach has its critics too, most notably Angus Maddison in The contours.... pp. 317-319. See also the discussion between Robert Allen $(2018,2019)$ on the one hand, and Jane Humphries and Jacob Weiskopf (2016) and Judy Stevenson (2018) on the other, regarding the level of English real wages before and during the early stages of the Industrial Revolution.

21 The only reference in literature to these data (and more exactly, to the construction worker wage only) is in Palairet (1995).

${ }^{22}$ Državopis (State Statistics), vol. I, 1863, Ministarstvo finansija (Ministry of Finance), p. 21.

${ }^{23}$ There are also wages of plough workers but they include the services of animals as well and thus cannot be used for labor compensation only. The disadvantage of using a mower's wage is its strongly seasonal character. 
number of cities covered by statistics continued to increase reaching 42 in 1910. The increase in the number of cities has no appreciable effect on the consistency of the series since the newly added cities did not differ from the old (as can be ascertained by comparing some prices from the two groups) and the small geographical size of the country ensured reasonable market integration. The "cities" were mostly small towns or townships however. The largest city in 1884 was Belgrade, with 35,500 inhabitants, and only two cities had more than 10,000 but fewer than 17,000 inhabitants. Two townships included in the list had less than one thousand inhabitants, and the average size of the towns from this list was just $6,600{ }^{24}$ Since even in these "towns" a lot of the population was engaged in agriculture, it could be said that most of our sample consists mostly of semi-urban settlements, that is, of a transitional type of settlement between the village and the real city. ${ }^{25}$

When creating the statistical base for this paper, for the period 1862-1880 we faced the problem of converting prices and wages from the kurus (or colloquially called Turkish grosch to distinguish it from the Austrian grosch) into dinars. The Turkish grosches were used for transactions and were thus reported in state statistics before the introduction of the dinar as the Serbian legal tender in 1879. At that time, the value of the dinar was fixed at 5 grosch (kuruş). After 1879, the statisticians recalculated the price and wage data for the earlier periods by dividing the grosch prices by 5 , i.e., by using the official exchange rate. However, according to the silver content of the dinar and the grosch, one dinar was worth only 4.5 grosch. ${ }^{26}$ (The dinar was officially worth 4.5 grams of silver vs. one gram of silver for the grosch. ${ }^{27}$ By using the 5-1 ratio, the Serbian authorities artificially reduced the value of the Turkish grosch in order to drive it out of circulation. So, we have two alternative dinar and grosch exchange rates: the official one of 5 to 1 , and the silver one of 4.5 to 1 . We have chosen to use the latter one because we consider it more accurate in strictly economic terms.

\footnotetext{
${ }^{24}$ Državopis (State Statistics), vol. XI, 1889, pp. 238-241.

25 For 1862, we have only the data on prices and wages for the second half of the year, since the recording began in mid-year. Therefore, the entire calculation for 1862 is valid, strictly speaking, only for the second half of the year, although the difference is unlikely to be significant.

${ }^{26}$ Following the rules of the Latin Monetary Union, the value of a dinar was fixed at 4.5 grams of silver, the same as the French franc.

${ }^{27}$ S.. Pamuk, A Monetary History of the Ottoman Empire, Cambridge University Press, 2009, p. 191.
} 
We have thus recalculated all prices and wages expressed in Turkish grosches (for the period 1862-1880) into nominal dinars using the exchange rate of 4.5 to 1.

The next problem has to do with weights. Until 1884, the measure of weight used in Serbian statistics was the old measure oka equal to $1.282 \mathrm{~kg}$. We have recalculated all quantities from oka into kilograms.

The subsistence and respectability baskets include respectively nine and twelve products: beans, meat, butter, soap, linen, candles, lamp oil, and fuel (for both), maize for the subsistence basket only, and bread (instead of maize) for the respectability basket; in addition, the respectability basket includes cheese, eggs and beer. We use, as already explained, two wage series which means that there are in total 15 prices per year (13 goods and two wages).

The data on maize, beans, meat, butter, eggs and soap prices are taken directly from the national statistics. ${ }^{28}$ For maize which was the most commonly used grain in Serbia, we use the retail price of maize flour. For meat, we take pork because it is the most common meat in Serbia. Instead of the yellow cheese, which is in Allen's basket, we included the socalled white cheese, which was practically exclusively used in Serbia in the $19^{\text {th }}$ century and whose price is included in state statistics. Since its calorific content is about half of that of the yellow cheese, we almost doubled its amount (9.75 kg instead of 5). Instead of beer, we included wine that was far more common in Serbia. We used the ratio of 1 liter of wine $=2.67$ liters of beer, as Allen suggested for countries where the use of wine was more common. ${ }^{29}$ In the official statistical sources, there is no price series for candles and lamp oil, but there is a price series for animal fat (tallow). Since in Serbia candles and oil for lamps were mainly made of tallow, we calculated the prices of candles and lamp oil by using the reported prices of animal fat and adjusting them by the observed ratio between the price of animal fat and the average of prices of candles or lamp oil found in other sources, mostly in newspapers. We had similar difficulties with linen cloth. Serbian statistics monitored the price of flax in kilograms, which we converted, using expert estimates, into square meters

\footnotetext{
${ }^{28}$ We used the following official statistical sources: Dry̌avopis (State Statistics) volumes I-XIX, Statisticki godišnjak (Statistical Yearbooks) 1893-1912 and Statistika cena poljoprivrednih proizvoda 1890-1905 (Statistics of the Prices of Agricultural Products 1890-1905). All were published by the Ministry of Finance.

${ }^{29}$ Robert C. Allen, "The Great Divergence in European Wages and Prices from the Middle Ages to the First World War“" Explorations in Economic History, October 2001, p. 421.
} 
(the unit in Allen's basket). We obtained the prices that are very close to those reported prices in square meters available in the contemporary newspapers. Finally, the 5 million BTU of fuel in the respectability basket (or alternatively 2 million BTU in the subsistence basket) came from the energy value of charcoal and its prices from national statistics.

Figure 2 shows, for illustrative purposes, the recorded prices of four important items: maize flour, bread, pork, and wine. The price of bread and maize is practically constant in nominal terms throughout. This was achieved through, at times, direct price controls by local authorities. The price of pork shows an increasing trend driven by the rising international, that is, export prices. The price of wine is very interesting as it clearly shows the effects of phylloxera that appeared in Serbia in the early 1880s and by 1897 destroyed most of vineyards.

Figure 2. Price of bread, maize flour, wine and pork, 1862-1910 (in nominal dinars)

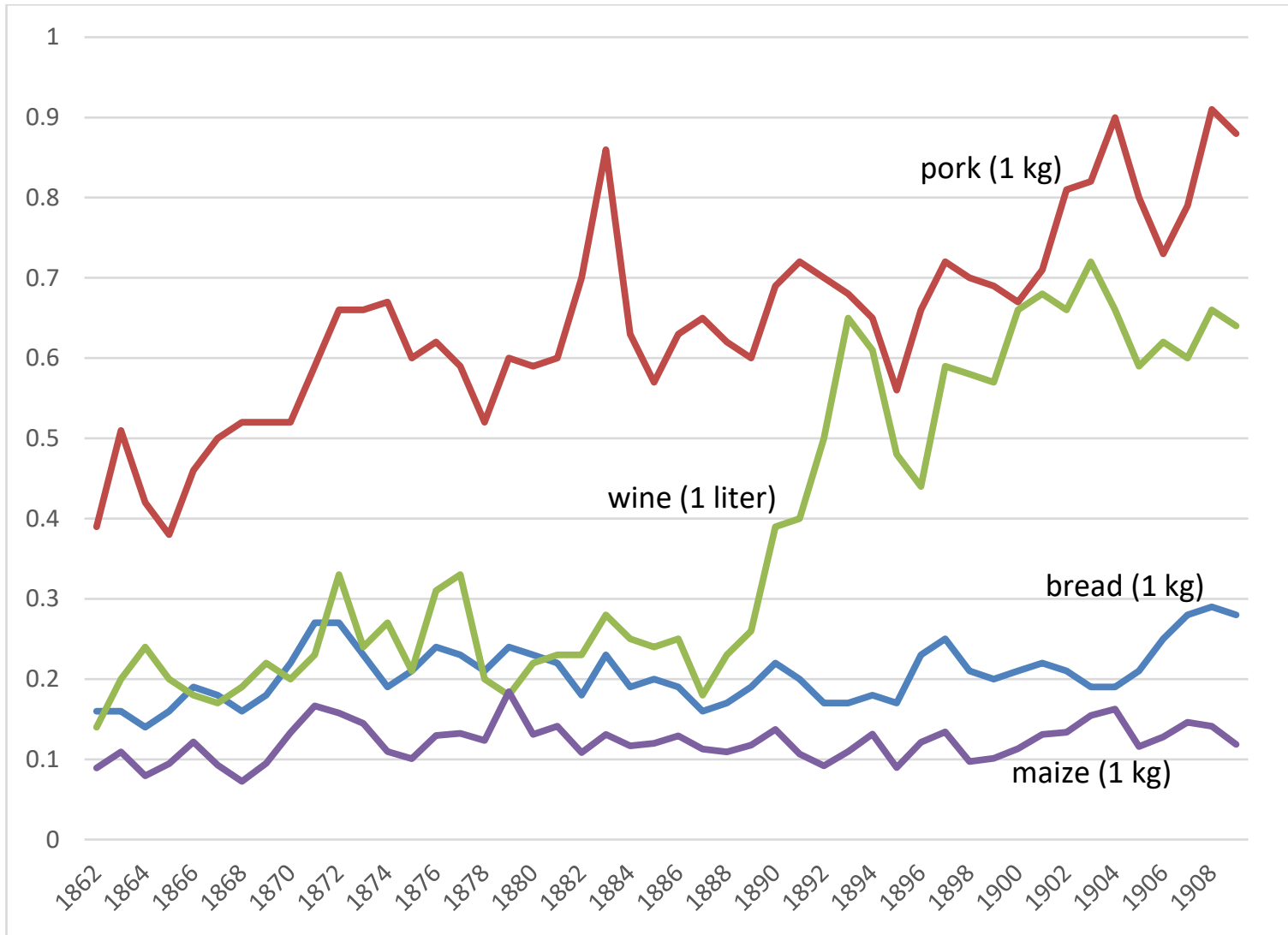

Table 1 shows the quantities of goods included in the respectability and subsistence baskets. The average cost of the respectability basket is three times that of the subsistence basket. Thus, as a rule of thumb, the welfare ratio calculated using the 
respectability basket would be about one-third of the welfare ratio obtained using the subsistence basket.

Table 1. Annual quantities of goods included in respectability and subsistence baskets

\begin{tabular}{|l|c|c|}
\hline Good (units) & Respectability basket & Subsistence basket \\
\hline Bread (kg) & 182 & \\
\hline Maize, flour (kg) & & 165 \\
\hline Beans (kg) & 40 & 20 \\
\hline Pork (kg) & 26 & 5 \\
\hline Butter (kg) & 5.2 & 3 \\
\hline Cheese (kg) & 9.75 & -- \\
\hline Eggs (ten) & 52 & -- \\
\hline Wine (liters) & 68.25 & -- \\
\hline Soap (kg) & 2.6 & 1.3 \\
\hline Linen (square m) & 5 & 3 \\
\hline Candles (kg) & 2.6 & 1.3 \\
\hline Tallow (liters) & 2.6 & 1.3 \\
\hline Charcoal (kg) & 170 & 68 \\
\hline Average annual cost over the period & 123 & 41 \\
\hline 1862-1910 (nominal dinars) & & \\
\hline
\end{tabular}

Note: Bare-bones subsistence basket from Allen, Murphy and Schneider (2012, Table 1, p. 873); respectability basket for Europe from Allen et al. (2011, Table 5, p. 25). For the conversion rates of charcoal/BTUs, wine/beer and yellow/white cheese see the text.

We use two types of workers' wages—-for the ordinary or unskilled workers, and for the skilled construction workers or masons. These are the two occupations and skill types used in similar calculations elsewhere both because of the availability of the data, and because they are clearly differentiated categories. Serbian statisticians' definitions are as follows: ordinary wages are earned by "ordinary wage-workers like diggers", or "ordinary farmer's helpers" ${ }^{30}$ while for skilled construction workers or masons it is said that they are "masters or apprentices who build themselves, not their helpers". Annual data for the two consumption baskets and two types of wages are provided in Annex 1.

The published wage data do not include food allowance as is explicitly stated in the official statistics. In Serbia, however, workers and masons usually received food from the employer. This was done so that workers would not waste time going back and forth between work site and home. We addressed the problem in two ways. First, we added to the reported wage for each year the nominal value of the food component of the subsistence

\footnotetext{
30 "Farmer's helpers" are included in the statisticians' instructions to the enumerators as to what an "ordinary worker's wage" means. It should be kept in mind that these are semi-urban settlements where "ordinary wage" of an urban digger is unlikely to be different from that of a farmer's helper.
} 
basket augmented for the wine from the respectability basket. Second, we looked at a large number of reports from villages, districts and counties (the three administrative tiers) regarding wages in their areas. These reports were published between 1870 and 1898 in the agricultural paper Težak. ${ }^{31}$ Around nine-tenths of the reports state that wages include food (and often wine and brandy as well), while about one-tenth of the reports provide only wages without food and alcohol. We also have a number of reports (twenty) which indicate wages with and without food. Most of food and drinks values range from 0.2 to 0.6 dinars per day, and one-half of them lie between 0.2 and 0.4 dinars. The average value of the food and drink allowance is 0.38 dinars per day. ${ }^{32}$ We added this amount to the published wages. We decided to keep this nominal amount for all the years because the actual data on implicit food values are dispersed across the years, are very scarce (so anchoring the value in any one year and deflating/inflating to other years would produce very different results depending on the anchor year), and they do not seem to vary systematically with the year when they were reported.

This is the way the statistical database was created. In total we needed 735 prices for the entire database (49 years x 15 variables per year). We took 671 data points (or more than 90 percent) from the official statistics. The missing 64 data points were filled in as follows: 8 from the contemporary newspapers and 56 through interpolation in the case of four products: eggs, soap, flax and coal for which the prices were not available in all the years.

Figure 3 shows the movement of nominal wages of unskilled and skilled workers and prices (proxied by the value of the respectability basket). As can be seen, the price level was broadly unchanged until the middle of the period (1888). Price growth then picked up at an average rate of about 2 percent per year and it continued until the end of the period. The reasons for this increase were mostly to be found in higher taxes (the introduction of excise duties and various city taxes), monetary expansion from the 1890s onwards, and the depreciation of silver, which was the monetary standard in Serbia, in the world compared to gold in the late $19^{\text {th }}$ and early $20^{\text {th }}$ centuries. The wage movement will be discussed below.

\footnotetext{
31 The information published in Tę̌a ak was provided by agricultural experts, teachers, priests, farmers.

${ }^{32}$ Note that this is a relatively high amount: the average daily unskilled wage was 1.35 dinars. However it is not unlikely that the cost (and quantity) of daily alcohol provided by the employer were substantial. Alcohol was often regarded as valuable and necessary as food.
} 
Figure 3. Nominal wages and prices, 1862-1910 (1862=100)

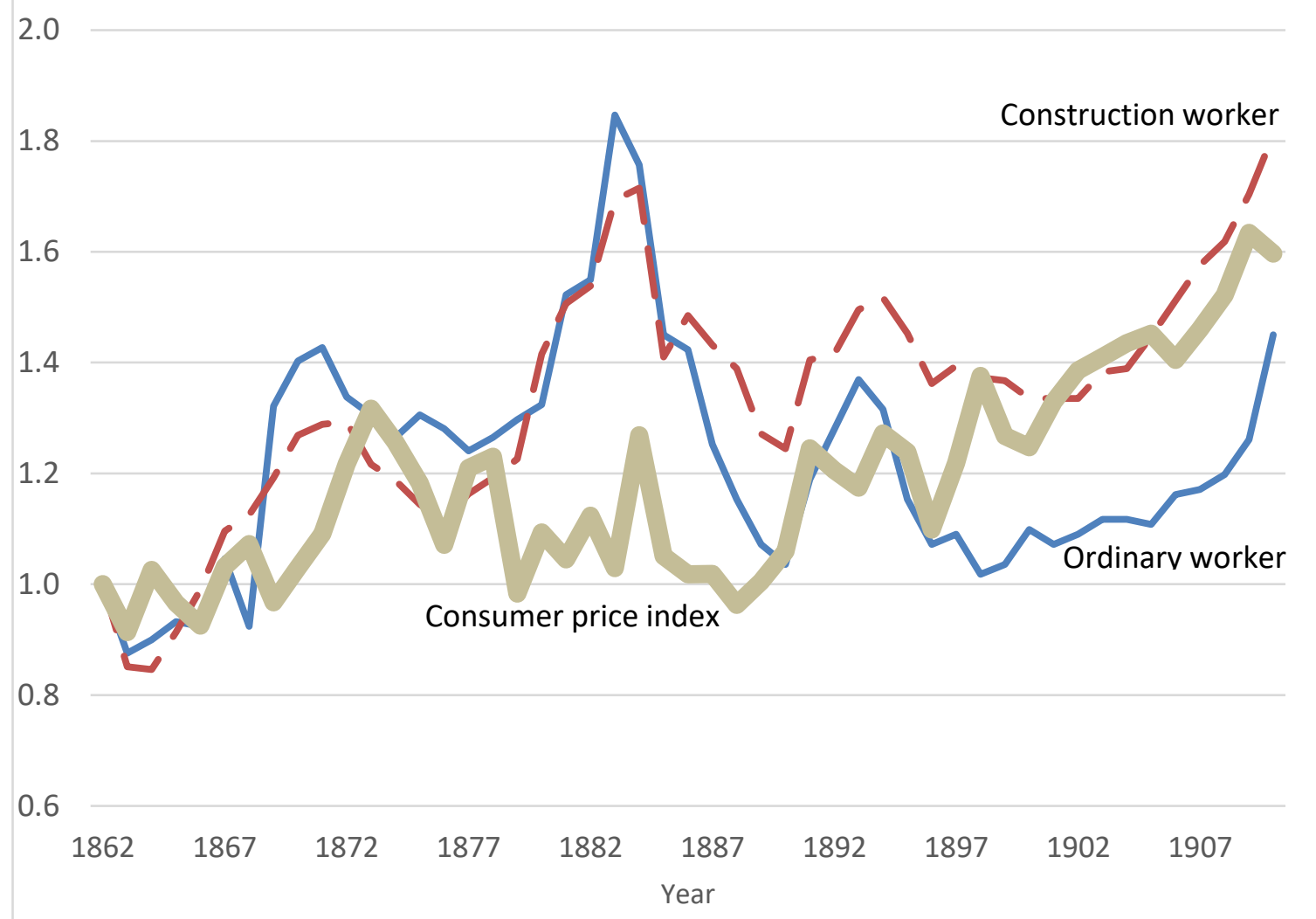

Source: See Annex 1. CPI is proxied by the cost of the respectability basket. Wages are nominal wages as given in the sources (that is, without the addition of food and drinks provided by the employer).

\section{Modified Allen's methodology}

In addition to including the non-monetary component of the wage, there are two additional modifications, required by the type of economy we are dealing with here, that we thought necessary to make. They are the assumed annual number of days of work and the average household size.

We address first the annual number of days of work. The common assumption in the literature, based largely on the West European experience, is that people worked for 250 days a year (see for example, Allen, 2009, p. 38). This number is, we believe, excessive for Serbia. There are frequent references in the contemporary magazines and newspapers on how little villagers worked and how many days were spent ("wasted") in various holidays, celebrations of the saints and the like - a feature that was also common in pre-industrialized Western Europe (see de Vries 2008). Furthermore, the very character of agriculture contributes to the fact that the number of working days was limited: agricultural work is 
heavily seasonal and in the late autumn and winter under a temperate continental climate, there is hardly any work to do. The same applies to construction. This is, of course, different from Western Europe which was more industrialized and where work depended less on climatic conditions. ${ }^{33}$

We did not however find claims by some authors that peasants were working only half-a-year or less credible. ${ }^{34}$ It seems that the number given ("less than half-a-year") is very approximate and is put forward for seemingly moralistic reasons intended to shame peasants. Instead we rely on the results of the rural survey conducted between 1910 and 1912 by Mihailo Avramović, the founder of the Serbian agrarian cooperative movement. ${ }^{35}$ According to the survey, 41 percent of the days go unused (either because of laziness, holidays, drinking ${ }^{36}$ or ill health), 45 percent of days are spent farming on own land, and 14 percent of days are spent "outside the estate" or "at home". Most of this latter category probably represent work, either through wage-earning, ${ }^{37}$ or on own property but outside agriculture (e.g. artisanal work). We thus estimate that farmers were working for slightly more than half a year and round off the number of working days at 200 , consistently with the assumptions often made for pre-industrial western Europe. ${ }^{38}$

The second adjustment to Allen's methodology refers to the number of family members whose needs are supposed to be covered by the wage earned by one member. As explained above, Allen assumes an average household size of 4, which on account of economies of scale in consumption and lower food needs of children, translates into 3 adult

\footnotetext{
${ }^{33}$ In a table showing the independent estimates of the days of work for England between 1560 and 1771, Allen and Weisdorf (2011, Table 1, p. 718) give the values ranging from 257 to 286, mildly increasing over time.

${ }^{34}$ For example, "farmers do not spend even one-half of 365 days working", Težak, 5 August 1890.

35 Avramovic, Naše seljačko gazdinstvo (Our farm economy), 1928, p. 29.

36 In 1869, an author writes: "In the summer at the peak of the seasonal field work, one can see in villages and even more so in towns, farmers who drink in inns or sleep the whole day, and at night they go hunting. Even when you offer them 20 grosch wage, they just make fun of you" (Težak, 10 May 1869).

37 This is confirmed by Avramović when he lists "personal earnings" which must include wages among the income of farms. Naše seljačko gazdinstvo, 1928, p. 35.

38 This is the number considered by Karl Gunnar Persson and Paul Sharp to have been quite common for the European pre-industrial societies, see Persson and Sharp, An Economic History of Europe: Knowledge, Institutions and Growth, 600 to the Present, Cambridge University Press, 2015, p. 75. Ridolfi (2019, p. 597) also assumes a year of 200 working days for the $17^{\text {th }}$ and $18^{\text {th }}$ century France. Stephenson (2019) finds that London construction workers in the early $18^{\text {th }}$ century worked 180 days.
} 
equivalent units. ${ }^{39}$ For Serbia in the $19^{\text {th }}$ century, however, household size of 4 is unrealistically low. Data from Population Censuses in Serbia show that the average household size varied between 6 and $7 .^{40}$ In accordance with that, we assume that the relevant number of family members that had to be maintained by a single wage-earner was 6 . ${ }^{41}$ Using the implicit Allen's scale of 1 for the first household member, and 0.667 for each additional member, yields 4-1/3 equivalent units (adult baskets). For housing needs, we, like Allen, add $5 \%$ of the total basket cost, and obtain thus a total of 4.55 equivalent units.

We believe that this modification gives a more realistic insight into what a subsistence wage in Serbia in the latter part of the $19^{\text {th }}$ century was supposed to cover. Of course, when we compare the Serbian real wage with that for other countries, the assumption of greater household size and fewer workdays pushes Serbian welfare ratios down. However, we believe this does not bias the results, but, on the contrary, presents a more realistic picture of the actual standard of living. If wage-earners work fewer days and have more household members whose needs wage ought to cover, then obviously the welfare ratio and the standard of living will be lower compared to the alternative case (more workdays and smaller household size). More generally, this raises the problem of how to do valid comparisons between different economies. We argue that the use of nationallyrepresentative household size and days of work is necessary if our objective is to use Allen's methodology to get an estimate of country's real per capita income. The blind application of the West European household size and annual days of work (at least as originally conceived

\footnotetext{
39 The use of the average family size of 4 is questioned even within the English context. Humphries (2011) argued that 4 was an unrealistically low estimate. Schneider (2012) introduces a further adjustment by exploring how the family size changes over the life cycle as the children are born, but also as many of them die at a relatively young age, or leave the family. Our data from the national statistical sources however are simple averages at a given point in time.

${ }^{40}$ See also Aleksandra Vuletić: "Koliko duša živi u jednoj kući? Broj članova seoskog domaćinstva u Srbiji 1834-1910” (“How many people live in a house? Number of village household members in Serbia 1834-1910”), Srpske studije, No 3, 2012.

41 There is an additional issue which due to the lack of data we cannot address here. The use of a single wage earner (generally male) assumes both that other members of the household (mostly women and children) do not work outside the home, and perhaps even more importantly, ignores entirely their work contribution which does not consist only in household tasks (which are not included in modern national accounts either) but work on the estate. The issue has recently been addressed by Humphries (2011) and Humphries and Weisdorf
} (2016). . 
by Allen) may, under the guise of equivalency, lead, on the contrary, to very misleading results for the countries where either or both of these assumptions do not hold. ${ }^{42}$

In addition, in an economy where farmers have the back-up of their own land holdings and where landlessness is minimal, the question can be legitimately raised whether the monetary wage (and the related welfare ratio) that is observed for only a fraction of total population can be implicitly used as a proxy for the welfare of the rural population that does not have much contact with urban and monetized economy. Technically, the approach is valid if rural and urban markets are well integrated and the observed urban wage reflects the net marginal product of farmers working on own farm. If the urban wage was less than the return from own farm (per unit of labor), and if landless peasants are few, we would not observe any supply of workers. If the urban wage was substantially above the return on own farm, we would likely observe a significant inflow of rural labor into industrial occupations. But in Serbia, as indicated above, we observe neither: we see the urban market and the rural sector (it is even not always correct to speak of "rural market") interacting at the edges, and being connected as the same people offered their services to work either in construction or on the farm, usually in the square of the town. Such semi-rural towns were fully integrated with the neighboring rural areas in social, economic and political sense. Further helping the integration between the two was the fact that occasional local labor shortages were eased by workers from other parts of the country or by temporary migrants. They came either from the more mountainous areas of Serbia (Užice, Zlatibor mountain, Vlasina, etc.) or from Austria-Hungary (mostly Serbs living there) or Bosnia (until 1878 under the Ottoman control and afterwards under Austro-Hungarian) and Bulgaria. ${ }^{43}$

\section{The results: discussion and comparison with other countries}

In the base-case scenario we use for both the construction worker and ordinary worker the assumption of 200 working days per year, six household members, and we add to the reported money wage the estimated value of the daily food allowance provided by the employer. The results (with respect to the subsistence basket) are shown in Figure 4.

\footnotetext{
42 This is similar to the issue faced by international price level comparisons: baskets cannot be blindly made the same for all regions or countries without losing local representativity (see Deaton 2010).

${ }^{43}$ Based on numerous articles published in Tę̆ak.
} 
Two different periods can be observed in the evolution of the welfare ratios for both skilled and unskilled labor: the first period lasting until the end-1880s in which both show an upward trend, and the second period of decline for ordinary workers and stagnation for construction workers. For the unskilled worker the welfare ratio thus ended in 1910 at the same level at which it was in the 1860s. The upward and then downward movement of unskilled wages differs from the two usual estimates of the dynamics of the Serbian economy over the same time period: some authors believe that Serbia experienced moderate growth, ${ }^{44}$ while Michael Palairet argues that real per capita income declined throughout. ${ }^{45}$

\footnotetext{
${ }^{44}$ R. Lampe and M. R. Jackson, Balkan Economic History, 1550-1950, From Imperial Borderlands to Developing Nations, Indiana University Press, 1982.

${ }^{45}$ Michael Palairet, The Balkan economies c. 1800-1914; Evolution without development, Cambridge University Press 1997; Şevket Pamuk, "Economic Growth in Southeastern Europe and Eastern Mediterranean, 1820-1914", Economic Alternatives, 2016, No. 3.
} 
Figure 4. Welfare ratio (using subsistence basket), urban Serbia 1862-1910

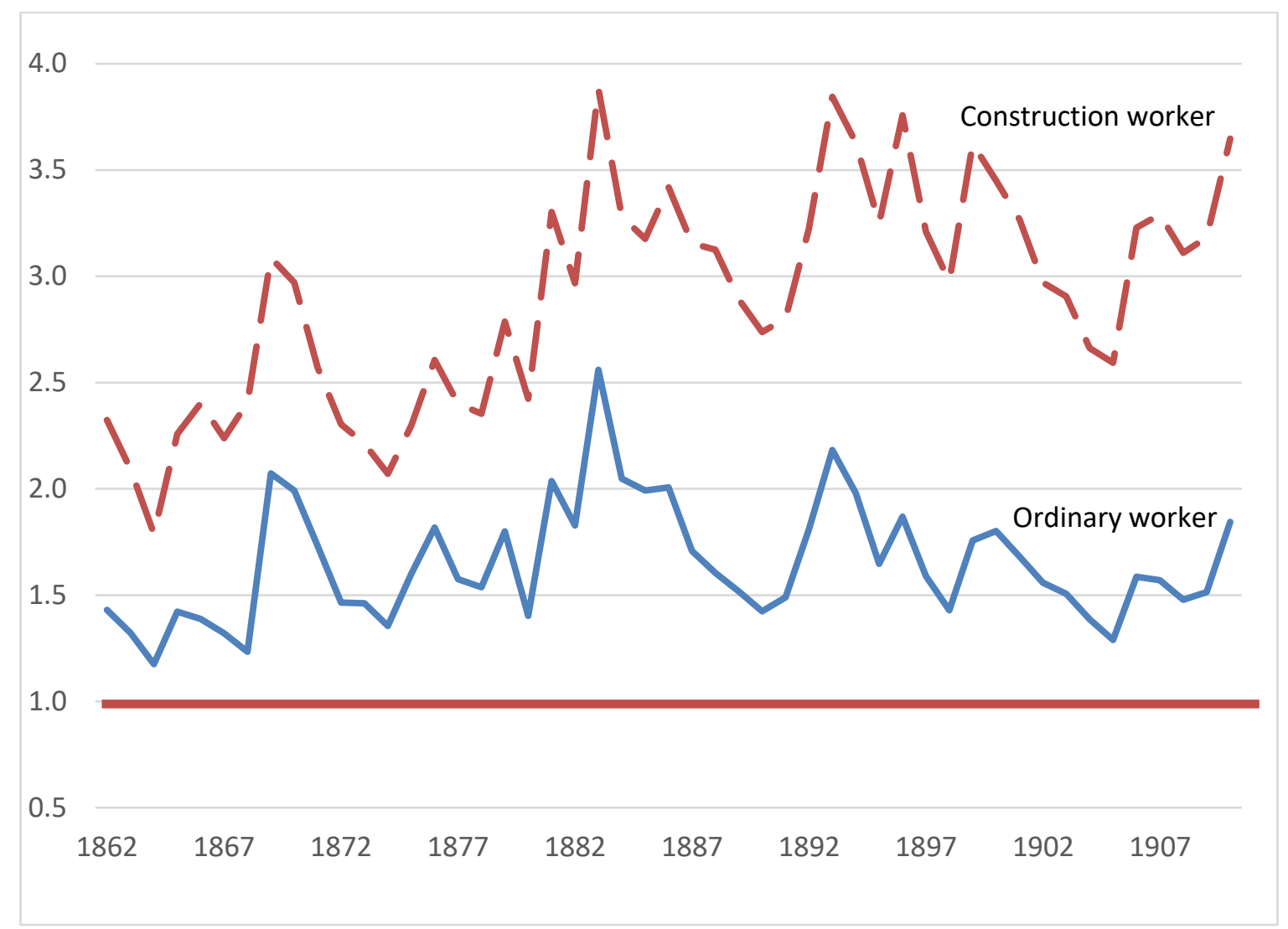

Note: Under the assumptions of 200 working days per year, household size of 6 , and inclusive of the daily food and wine allowance provided by the employer.

The period of generally increasing wages between 1862 and the late 1880s is composed of two subperiods of attempted modernization (the latter through significant foreign borrowing) separated by a short war. The first increase of real wages from the mid1860s to 1870 coincides with the reign of Prince Mihailo Obrenović, an enlightened monarch keen to modernize the country. In the economic sphere, the most important measure of his government was the creation of The Directorate of Funds (Uprava fondova, in Serbian) in 1862. The Directorate of Funds was a credit organizations with a very large initial capital of around 17 million dinars, which was $1 \frac{1}{2}$ times the state budget in that year. It was also seen as a social institution whose role was to help peasants in financial difficulties. The Directorate's loans went principally to large peasants and traders. ${ }^{46}$ This encouraged

\footnotetext{
${ }^{46}$ Djordje Pavlović, "Predlog za uređenje težačkog kredita u Srbiji” [Proposal for the improvement of agricultural credit system in Serbia], Težak, 30.5.1870.
} 
economic activity, increased exports (by 123 percent from 1861-1870, due mostly to the Hungarian demand for corn and wheat $\left.{ }^{47}\right)$ and led to higher wages. ${ }^{48}$

However, in the following years, real wages stagnated because of the SerbianTurkish wars of 1876-1878 which slowed down economic activity and brought difficulties in the countryside where the military requisitioned food from peasants. When the economy began its recovery from the wars in 1881, wages experienced significant growth (16 percent for skilled, 21 percent for unskilled).

In 1881 began a relatively short period (lasting until 1888) of considerable foreign borrowing by Serbia. The aim was to jump-start the process of "modernization". ${ }^{49}$ This brought in a lot of foreign money into the country and allowed for the highest wage level recorded during the entire 1862-1910 period.

The period of the long-term unskilled wage decline began in 1888, when net foreign borrowing stopped as Serbia experienced difficulties with debt servicing. The fiscal pressure also significantly increased in order to repay foreign loans. Thus the budget revenues almost doubled in ten years, passing from 22.9 million dinars in 1880 to 44.9 million in $1890 .^{50}$ In real terms, the increase was even greater as our data from both the respectability and subsistence baskets show a mild price deflation. Tax per person and tax revenues as a share of GDP (even if we do not yet have the data for the latter) almost certainly increased. Also during the 1880s cheap American wheat appeared in the European markets. Serbian wheat now had to compete with the American, leading to a stagnation of total exports, as well as to the worsening terms of trade.

\footnotetext{
${ }^{47}$ John Komlos, The Habsburg Monarchy as a Customs Union, 1983, pp. 75-78.

${ }^{48}$ However, the lending for agriculture by the Directorate of Funds dried out soon because the borrowers failed to repay many loans, leading a Minister of the Economy to lament the fact that the Directorate was "in a sad state" because its "capital that is being loaned out ...is paid back only with difficulty and in a disorderly fashion". Using the legal system to force repayments or seize assets was out of the question because of the huge number of non-performing loans. Not surprisingly, private banks did not lend to agriculture, considering business too risky because of the inalienable homestead and unclear property rights.

${ }^{49}$ Former Finance Minister Vladimir Jovanović described the plan as follows: "Since Serbia is not rich in capital, it was thought that the loans made from foreign capital will virtually "rain millions of gold coins over the population", multiply its production resources, increase revenues, and improve tax and financial strength [of the economy]. In that hope, a number of foreign loans for Serbia have been raised ", Vladimir Jovanović, Izabrani spisi [Selected papers], 2011, p. 469.

${ }^{50}$ Boško Mijatović, Istorija državnih finansija Srbije 1876-1895 (History of Serbia's State Finances, 1876-1895), Arhipelag, 2020.
} 
The next local peak of real wages was in 1893-1894. The reason for the growth was an abundance of money that the National Bank issued in previous years (currency in circulation doubled in the previous three years to cover the budget deficit) without a corresponding increase in the price level.

Another important episode, with a negative impact on real wages, was the multiyear trade war (the so-called "pig war") between Austria-Hungary and Serbia. The war began in 1905 when Austria-Hungary introduced special sanitary controls whose objective was to reduce Serbian exports and exert a political pressure on the new Serbian government that was seen by Vienna as pro-Russian. The result was an 80 percent decrease in Serbia's exports to Austria-Hungary, a country that was then by far the largest foreign trade partner of Serbia. In fact, no less than 89.8 percent of total Serbian exports in 1905 went to Austria-Hungary. ${ }^{51}$ Serbia tried, and mostly managed, to re-orient its exports to the markets of other countries, such as Germany, Belgium and France. At the same time, faster growth of the industry began through a policy of import substitution, driven by the increase in customs duties on Austro-Hungarian industrial goods which until then were dominant in the Serbian market.

The ordinary worker's welfare ratio was, except for approximately the decade of the 1880s always between 1 and 2 times the subsistence, with an overall average of 1.65 (Figure 4). This means that an unskilled worker's wage was above the level that is just sufficient to cover the elementary needs of himself and his family. The improvement which sets in the early 1880s was relatively short-lived and by the end of the century the welfare ratio dropped back to where it was in the beginning of the period. It stayed at that level until 1910 when our data end. Thus the welfare ratio of an ordinary worker does not show any sustained improvement over half-century.

It is useful to check how dependent are our conclusions regarding the wage level and its evolution on the assumptions made in the base-case scenario. Table 2 shows the welfare ratios in the first ten years of the period (1862-71) and in the last ten years (1901-1910) when the number of working days and the value of food received in kind vary. The absolute level of the welfare ratio obviously changes in function of the number of days worked while the shift-change (in the number of days) leaves the relative ratios between the end-period and

\footnotetext{
51 Statistickei godisnjak Kraljevine Srbije za 1907 i 1908 (Statistical Yearbook of the Kingdom of Serbia for 1907 and 1908), vol. XII, 1913, p. 506.
} 
the beginning-period wages the same (columns 1-3). When we price the food and wine components from the baskets, the end-period welfare ratio for the unskilled worker is practically the same as in the beginning. When we use the same nominal amount for the inkind wage, the welfare ratio at the end is some 6 percent lower than in the beginningreflecting, as mentioned, probably a bias in favor of the early years (columns 4-6). Our basecase scenario (column 2) yields relatively low, although not the lowest, welfare ratio compared to the other scenarios. Under the most optimistic scenario when the workyear is assumed to be 250 days and the value of the food allowance is relatively high, the end-point welfare ratio for an ordinary worker is 2.14 (see column 6) rather than 1.54 as in the basecase.

Table 2. Unskilled and skilled worker's subsistence welfare ratio under different assumptions

\begin{tabular}{|c|c|c|c|c|c|c|}
\hline & 1 & $\begin{array}{c}2 \\
\text { (Base case) }\end{array}$ & 3 & 4 & 5 & 6 \\
\hline $\begin{array}{l}\text { Value of food } \\
\text { received in kind }\end{array}$ & \multicolumn{3}{|c|}{$\begin{array}{c}\text { Food components of the subsistence } \\
\text { basket plus wine from the respectability } \\
\text { basket }\end{array}$} & \multicolumn{3}{|c|}{$\begin{array}{l}\text { Based on documentary evidence } \\
\text { (food and drinks }=0.38 \text { dinar) }\end{array}$} \\
\hline $\begin{array}{l}\text { Annual number of } \\
\text { days of work }\end{array}$ & 180 & 200 & 250 & 180 & 200 & 250 \\
\hline \multicolumn{7}{|l|}{ Unskilled wage } \\
\hline $\begin{array}{l}\text { Average welfare } \\
\text { ratio } 1862-71\end{array}$ & 1.36 & 1.51 & 1.89 & 1.64 & 1.87 & 2.28 \\
\hline $\begin{array}{l}\text { Average welfare } \\
\text { ratio 1901-1910 }\end{array}$ & 1.39 & 1.54 & 1.93 & 1.54 & 1.71 & 2.14 \\
\hline $\begin{array}{l}\text { Improvement of the } \\
\text { welfare ratio }\end{array}$ & $+2 \%$ & $+2 \%$ & $+2 \%$ & $-6 \%$ & $-6 \%$ & $-6 \%$ \\
\hline \multicolumn{7}{|l|}{ Skilled wage } \\
\hline $\begin{array}{l}\text { Average welfare } \\
\text { ratio } 1862-71\end{array}$ & 2.17 & 2.41 & 3.02 & 2.45 & 2.73 & 3.41 \\
\hline $\begin{array}{l}\text { Average welfare } \\
\text { ratio 1901-1910 }\end{array}$ & 2.78 & 3.09 & 3.86 & 2.93 & 3.26 & 4.07 \\
\hline $\begin{array}{l}\text { Improvement of the } \\
\text { welfare ratio }\end{array}$ & $+28 \%$ & $+28 \%$ & $+28 \%$ & +19 & $+19 \%$ & $+19 \%$ \\
\hline
\end{tabular}

Although the construction worker's welfare ratio moves partly in tandem with that of the ordinary worker, it does shows some improvement. At the end of the period in the base-case scenario, construction worker's welfare ratio is 3.1 while in the beginning of the period it was 2.4 (see Table 2). Under all scenarios, skilled worker's wage is higher at the end of the period (by between 19 and 28 percent) than in the beginning.. There is thus an increasing gap between the two wages. While until 1890, the ratio between the skilled and 
unskilled wage was almost fixed at 1.5 to 1, from around 1890, the construction worker's welfare ratio_-and thus his real wage-gradually increased and became twice as high as that of an ordinary worker. ${ }^{52}$ This can be seen in Table 2 (base-case scenario) by calculating the ratio between skilled and unskilled labor at the end of the period $(3.09 / 1.54=2)$ and at the beginning $(2.41 / 1.51=1.6)$.

Why did wages of construction workers rise compared to the wages of unskilled workers? It was probably related to significant increases in construction activities throughout the second half of the $19^{\text {th }}$ century, the growth of cities, new state offices and military buildings, and infrastructural investments, including the construction of the first railroad in Serbia (started in 1881 and completed in 1884). It probably also reflects a slow increase in more skilled workers that, as argued before, has characterized Serbian economy throughout the $19^{\text {th }}$ century. ${ }^{53}$

52 The same lack of real wage growth among unskilled labor and increase in the skilled wage between 1860s and 1910s is reported for Istanbul by Özmucur and Pamuk (2002, Table 1, p. 301 and Figure 1, p. 306). While the unskilled wage there shows some fluctuations, its decennial 1900-10 level was lower than in 1850-59. The wage of skilled workers however displayed a constant increase.

${ }^{53}$ In that respect Serbia lagged behind similar Balkan countries like Bulgaria which moreover achieved their independence much later. (The latter point is relevant because improved education in continental Europe was often a state-led project with strong nationalist and even militaristic undertones; see e.g. Hobsbawm, 1996 and more specifically for Eastern Europe, Gellner, 1983) Around 1900, Bulgaria's literacy rate was just under 30\% (see Daskalova, 2017, p. 64) while literacy in Serbia was, as mentioned above, only 17\%. 
Table 3 displays the welfare ratios using the respectability basket (shown only for the base-case scenario of 200 working days, and with employer-provided food and wine ). The cost of the respectability basket has clearly outstripped the rise in unskilled wage so that at the end of the period the wage of an ordinary worker was some $20 \%$ lower than in the beginning, while the wage of a construction worker was the same as in the beginning. We can thus propose the following stylized facts:

Table 3. Unskilled and skilled worker's welfare ratio based on respectability basket

\begin{tabular}{|l|c|c|}
\hline Average welfare ratio & Unskilled wage & Skilled wage \\
\hline Average welfare ratio 1862-1871 & 0.55 & 0.88 \\
\hline Average welfare ratio 1901-1910 & 0.44 & 0.88 \\
\hline Improvement of the welfare ratio & $-20 \%$ & $0 \%$ \\
\hline
\end{tabular}

1. Unskilled wage moved with the subsistence basket and stayed at the level of about 1.5-1.6 times the subsistence (taking the base-case assumptions).

2. Skilled wage premium (in relationship to unskilled wage) increased from about 1.5 to 2 but that increase just maintained skilled wage's purchasing power in terms of the respectability basket.

3. The implication is not only that the cost of the respectability basket rose much more than the cost of the subsistence basket, but that the two wages seemed to have been "indexed" to different baskets: the wage of an ordinary worker to the subsistence basket, and the wage of a skilled worked to the respectability basket.

We are agnostic as whether this was an accidental development or there may be grounds to believe that in slowly developing economies the two different wages (skilled and unskilled) are implicitly indexed to different baskets; in other words, that the socially acceptable needs are differentiated depending on what kind of workers we deal with. 
Figure 5. Ordinary worker's wage in relations to subsistence, construction worker's wage in relation to the respectability basket

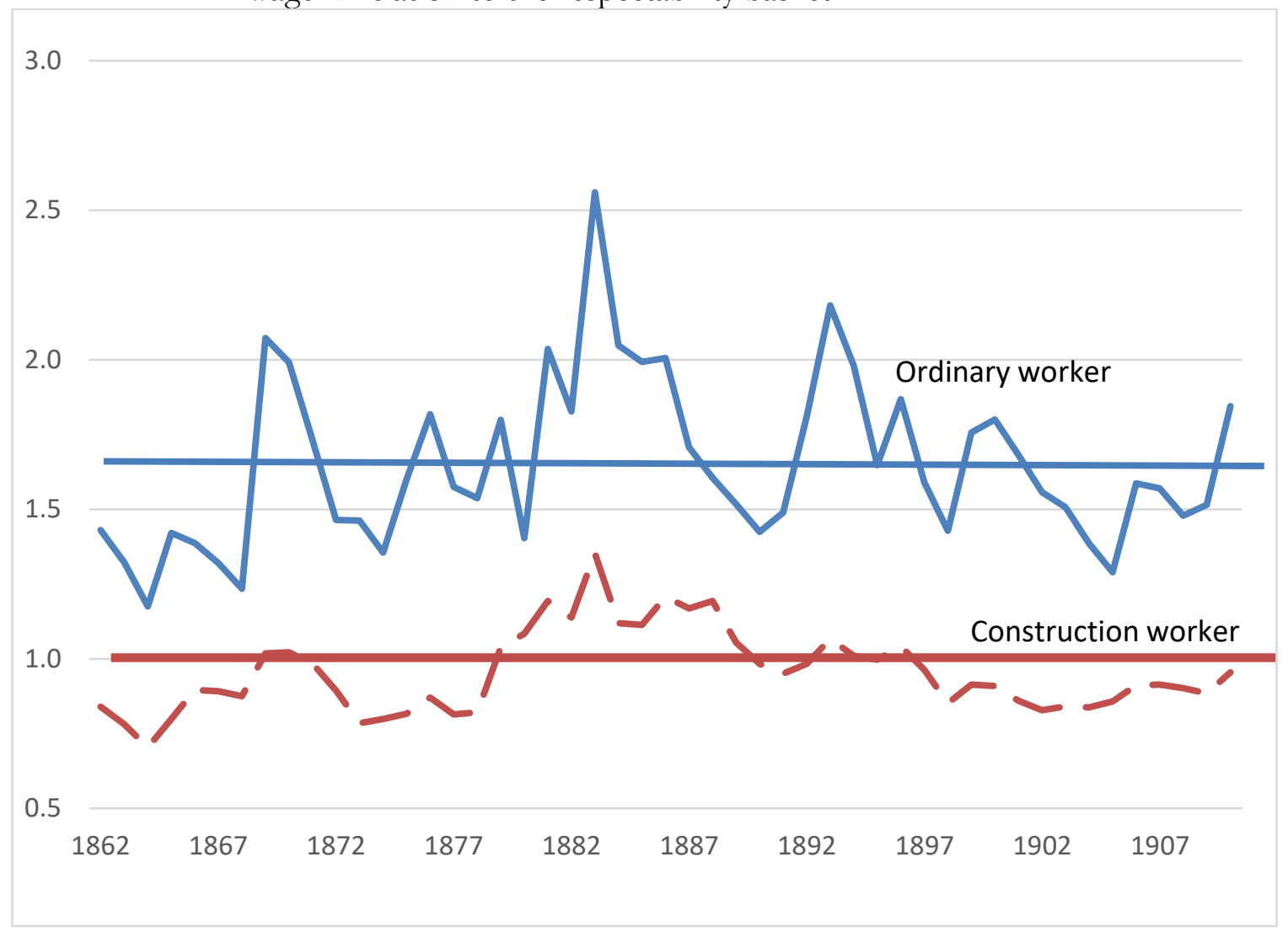

This possible implicit indexing is illustrated in Figure 5 where we calculate the welfare ratios of the unskilled worker with respect to subsistence, and the welfare ratio of the skilled wage with respect to the respectability basket. If we "index" ordinary worker's wage to the subsistence basket, the coefficient of variation during the entire period is 0.17 ; if we "index" the construction worker's wage to the respectability basket, the coefficient of variation is even smaller: 0.14 . So both varied very little if "indexed" to their putative correct baskets.

We turn next to what can be said about Serbian real wages in the international context and how our results compare with those for other countries. A useful starting point is the perception of Serbian writers who have lived in more developed parts of Europe of Serbia's workers' relative income position. In his book Srbija na Istoku (Serbia in the East), published in 1872, Svetozar Marković, a pre-eminent Serbian socialist who did his studies in Switzerland, wrote the following: "Earnings of a qadruga farmer before the Serbian revolution [in the early 1800s] and probably today as well hardly exceed the earnings of an average worker in Europe. I do not take here the money value of earnings but the quantity 
of essential goods that each of them can buy with his labor. And today's Serbian peasant, if he does not live worse, surely does not live better than the working people in the West" (p. 32). ${ }^{54}$

We can now, almost 150 years after Marković speculated, answer that question empirically. All data in Table 4 except for Serbia come from Allen et al. (2011), a study that compares European and Asian real wages. Allen et al. find not only that North European wages were higher than Chinese or Japanese wages around 1860-70 but that in the next halfcentury they tended to increase at a greater rate. This is especially clear in the case of Leipzig (and presumably German) real wages that recorded the highest rate of growth. For China, Allen et al. conclude (p. 27) that "The standard of living in China remained low and on a par with the regions of Europe untouched by the Industrial Revolution". This is what we find. Serbian unskilled real wage which around 1860-70 were low but higher than the equivalent wages in Milan and Kyoto/Tokyo remained at that low level in the next fifty years while the real wages in Milan and Kyoto/Tokyo doubled or more than doubled. Like the Chinese real wage, Serbian unskilled real wage registered no growth. Therefore, the gap between, on the one hand, Northern Europe as well as Southern Europe (represented by Milan here), and on the other hand, Serbia and probably the rest of South-East Europe widened considerably. So if Marković has not been widely off the mark in his assessment of Serbia's working people position vis-à-vis at least some European countries in the early $19^{\text {th }}$ century, he was too optimistic in his assessment of the situation in 1860-1870. Serbia's economic backwardness (compared to industrializing nations), which will deepen in the ensuing decades, was already advanced.

\footnotetext{
${ }^{54}$ Note here Marković's very modern idea of using a basket of "essential goods" to compare wages internationally.
} 
Table 4. Unskilled worker's subsistence-based welfare ratio

\begin{tabular}{|l|c|c|c|}
\hline & $1860-1870$ & $1900-1910$ & $\begin{array}{c}\text { Average decennial } \\
\text { increase (in percent) }\end{array}$ \\
\hline London & 4.7 & 8 & 11 \\
\hline Oxford & 4.3 & 6 & 7 \\
\hline Amsterdam & 2.7 & 6 & 17 \\
\hline Leipzig & 2.4 & 6.2 & 21 \\
\hline Milan & 1 & 2.1 & 16 \\
\hline Kyoto/Tokyo & 1 & 2 & 0 \\
\hline Beijing & 1 & 1 & 0.5 \\
\hline $\begin{array}{l}\text { Urban Serbia (average } \\
\text { household size=6) }\end{array}$ & 1.51 & 1.54 & \\
\hline
\end{tabular}

Source: urban Serbia, see the text (base case scenario with 200 working days); other cities from Allen, Basino, Ma, Moll-Murata and Van Zanden, "Wages, prices, and living standards in China, 1738-1925: in comparison with Europe, Japan, and India”, Economic History Review, vol. 61, S1, 2011, Tables 5 and 6.

\section{Conclusions and some reflection on the methodological issues}

Our key conclusion is that Serbia, and likely most of South-East Europe, diverged from western Europe's standard of living during the second half of the $19^{\text {th }}$ century and the first decade of the $20^{\text {th }}$ century. Taking London as a comparator, the ratio between the welfare ratio in London and that in urban Serbia widened from about 3 to 1 in the 1860 s to more than 5 to 1 just prior to World War I. These results are not surprising in the light of what we know from other sources regarding slow or even non-existent growth of agricultural Balkan economies in the $19^{\text {th }}$ century. In fact, our data show that the welfare ratio of unskilled worker was the same in the first decade of the $20^{\text {th }}$ century as it was in the beginning of the period (1860s). However, the welfare ratio of skilled construction workers was 20 to 30 percent higher at the end than at the beginning of the period, which does reflect some modest progress. (In terms of the respectability basket however it was unchanged.)

We also noted that ordinary worker's wage seemed to move more closely with the cost of the subsistence basket, while the construction (skilled) worker's wage seemed to vary with the cost of the respectability basket. This has led us to hypothesize that-perhaps driven by custom - the wages of the two kinds of workers were implicitly "indexed" to different baskets which represented what was socially regarded as "due" to respectively ordinary and more qualified workers. This may not be the case in a growing economy that in principle should pull everybody up, but may be present in a stagnant economy like Serbia's in the $19^{\text {th }}$ century. 
While adjusting Allen's methodology to the contemporary circumstances of Serbia, we have proceeded to three modifications: we include in total wage its non-cash component, argue that the average number of days worked annually was 200 rather than 250, and use the average household size of 6 rather than 4 . These departures from the "canonic" literature are important not only for this text, but more generally.

The inclusion of the non-cash component of wage is not controversial. One should in principle do it, provided of course such information is available.

The number of days of work and the average household size however raise the issue of what the methodology we use is really after. Welfare ratios serve as proxies for the welfare not of workers only, but of the entire population. If we were interested in the welfare of workers, there would be no need to include the cost of the family consumption basket; for a worker alone, the cost of his/her basket would have been sufficient. For this reason, we believe that in principle studies should use countries' average household sizes and not try to mechanically replicate the use of west European household size of 4. Similarly, using country specific number of days of work yields more accurate results than the use of the west European average (which is indeed quite contested for western Europe as well). If people do not work much and have many family members, their real per capita income will be lower than in the opposite case (even if their own real wage per unit of effort may not be). The real cross-country comparability is achieved by using country-specific (that is, different) assumptions, and not be using the pre-determined assumptions regarding the demographic structure, hours of work or any other relevant parameter.

In addition, one should (which due to the lack of data we were unable to do here), include the monetary contribution as well as the imputed value of goods and services produced by other members of the households. All of there adjustments imply that the purpose of the welfare ratios is to proxy the standard of living of a population, not the real wage of a worker. 


\section{References}

Allen, Robert C., (2001), "The Great Divergence in European Wages and Prices from the Middle Ages to the First World War", Explorations in Economic History, vol. 38, pp. 411-447.

Allen, Robert C. (2005), "Real Wages in Europe and Asia: A first look at the long-term patterns", in Living Standards in the Past: New Perspectives on Well-Being in Asia and Europe, edited by Robert C. Allen, Tommy Bengtsson, and Martin Dribe, Oxford, Oxford University Press.

Allen, Robert C. (2009), The British Industrial Revolution in Global Perspective, New Approaches to Economic and Social History, Cambridge.

Allen, Robert C. (2017), “Absolute poverty: When necessity displaces desire”, American Economic Review, vol. 107, No. 10 (December), pp. 3690-3721.

Allen, Robert C. (2018), "Spinning their Wheels: A Reply to Jane Humphries and Benjamin Schneider", University of Oxford Discussion Papers in Economic and Social History, Number 166.

Allen, Robert C. (2019), "Real wages once more: a response to Judy Stephenson", The Economic History Review, vol. 72 (2), pp. 738-754.

Allen Robert C., Jean-Pascal Bassino, Debin Ma, Christine Moll-Murata and Jan Luiten van Zanden (2011), "Wages, prices, and living standards in China, 1738-1925: in comparison with Europe, Japan, and India”. The Economic History Review, vol. 64, pp. 8-36.

Allen, Robert and Ekaterina Khaustova (2017), "Russian real wages before and after 1917”, New York Universitty Abu Dhai Wrking Paper 0003, May. Available at https://nyuad.nyu.edu/content/dam/nyuad/academics/divisions/social-science/workingpapers/2017/0003.pdf.

Allen, Robert C., Tommy E. Murphy and Eric B. Schneider (2012), "The colonial origins of the divergence in the Americas: A labor market approach", The Journal of Economic History, vol. 72 , no. 4 , December.

Allen, Robert C. and Jacob Weisdorf (2011), "Was there an industrious revolution before the industrial revolution? An empirical exercise for England, c. 1300-1830". The Economic History Review, vol. 64, No. 3, pp. 715-729.

Antonić, Slobodan (2014), "Demokratija u Srbiji uoči Prvog svetskog rata" (Democracy in Serbia on the eve of the First World War"), Socioloskki pregled, vol. XLVIII, no. 4.

Braudel, Fernand (1984), The Perspective of the World: Volume III: Civilization and Capitalism, $15^{\text {th }}-18^{\text {th }}$ century, translated by Siân Reynolds, Harper and Row, New York. Originally published in French in 1979.

Broadberry, Stephen and Bushnupriya Gupta (2016), "The early modern great divergence: wages, prices and economic development in Europe and Asia, 1500-1800”, Economic History Review, vol. 59, pp. 2-31. 
Cvrček, Tomáš (2013), "Wages, prices and living standards in the Habsburg Empire, 18271910”, Journal of Economic History, March, pp. 1-31.

Daskalova, K. (2017). "Developments in Bulgarian Education: from the Ottoman Empire to the Nation-State and beyond, 1800-1940s", Espacio, Tiempo y Educacion, 4(1), pp. 1-29.

Deaton, Angus (2010), "Price Indexes, Inequality, and the Measurement of World Poverty", American Economic Review, vol. 100, No. 1, pp. 5-34.

de Vries, Jan (2008), The Industrious Revolution: Consumer Behavior and the Household Economy, 1650 to the Present, Cambridge University Press.

de Zwart, Pim and Jan Luiten Van Zanden (2015), "Labor, wages, and living standards in Java, 1680-1914”, European Review of Economic History, vol. 19, Issue 3, August, pp. 215-234.

Gellner, Ernest (1983), Natons and nationalism, Cornell University Press.

Hobsbawm, Eric (1996), The Age of Revolutions, 1789-1848, Vintage Books. Originally published in 1962.

Humphries, Jane (2011), "The Lure of Aggregates and the Pitfalls of the Patriarchal Perspective: A Critique of the High-Wage Economy Interpretation of the British Industrial Revolution", Discussion Papers in Economic and Social History, University of Oxford, No. 91.

Humphries, Jane and Jacob Weisdorf (2016), "Unreal wages? A new empirical foundation for the study of living standards and economic growth in England, 1260-1860", University of Oxford, Discussion paper on economic and social history, Number 147, September.

Lewis, Arthur W. (1954), "Economic Development with Unlimited Supplies of Labour", Manchester School, vol. 22, May.

Li, Bozhong and Jan Luiten van Zanden (2012), "Before the Great Divergence: Comparing the Yangzi delta and the Netherlands at the beginning of the nineteenth century", The Journal of Economic History, vol. 72, No. 4, pp. 956-989.

Lindert, Peter H. and Jeffrey G. Williamson (2014), "American incomes before and after the Revolution”, National Bureau of Economic Research Working Paper 17211, July. Available at

http://citeseerx.ist.psu.edu/viewdoc/download?doi=10.1.1.352.5624\&rep=rep1\&type=pdf. (accessed 18 December 2018).

Marković, Svetozar (2016), Srbija na istoku (Serbia in the East), Prosveta, Belgrade. Originally published in 1872 .

Mijatović:, Boško (1995), “Zaštita seljaka od finansijskih rizika u nekadašnjoj Srbiji” ("Protection of peasants from financial risks in Serbia"), Glas SANU, Odeljenje društvenih nauka, vol. 27. 
Mijatović, Boško (2019), Istorija držaunih finansije Srbije 1876-1895 (History of Serbia’s State Finances, 1876-1895), Arhipelag.

Özmucur, Suleyman and Şevket Pamuk (2002), "Real Wages and Standards of living in the Ottoman Empire, 1489-1914", The Journal of Economic History, vol. 62,. No. 2.

Palairet, Michael (1995), "Real wages and earnings in long-run decline: Serbia and Yugoslavia since 1862", in Peter Scholliers, Vera Zamagni (eds.), Labour's reward: real wages and economic change in 19th- and 20th-century Europe, Edward Elgar.

Palairet, Michae (1997), The Balkan economies c. 1800-1914; Evolution without development, Cambridge University Press.

Pamuk, Şevket (2006), "Urban Real Wages Around the Eastern Mediterranean in Comparative Perspective, 1100-2000" in in Alexander J. Field, Gregory Clark, William A. Sundstrom (ed.) Research in Economic History, Volume 23, Emerald Group Publishing Limited.

Pamuk, Şevket (2007), "The Black Death and the origins of the 'Great Divergence' across Europe, 1300-1600”, European Review of Economic History, vol. 11, 2007, pp. 280-317.

Pamuk, Sevket (2016), "Economic Growth in Southeastern Europe and Eastern Mediterranean, 1820-1914", Economic Alternatives, No. 3.

Ridolfi, Leonardo (2019), "Six Centuries of Real Wages in France from Louis IX to Napoleon III: 1250-1860”, The Journal of Economic History, Vol. 79, No. 3 (September).

Phelps Brown, Henry E. and Sheila V. Hopkins (1962). "Seven Centuries of Building Wages" in Essays in Economic History, vol. 2, ed. E. Carus-Wilson, Edward Arnold Publishers, London.

Stephenson, Judy Z. (2018), “' Real' wages? Contractors, workers, and pay in London building trades, 1650-1800', The Economic History Review, vol. 71 (1), pp. 106-132.

Stephenson, Judy Z. (2019), "Working days in a London construction team in the eighteenth century: evidence from St Paul's Cathedral”, The Economic History Review, published 18 September 2019. https://onlinelibrary.wiley.com/doi/abs/10.1111/ehr.12883 (accessed 25 November 2019).

Schneider, Eric (2012), "Real wages and the family: Adjusting real wages to changing demography in pre-modern England", University of Oxford, Discussion Papers in Economic and Social History, University of Oxford, Number 99, May.

Trgovčević, Ljubinka (1994), "Obrazovanje kao činilac modernizacije u Srbiji u XIX veku” (Education as a factor of modernization of Serbia in the $19^{\text {th }}$ century) in Latinka Perović (ed.) Srbija u modernizacijskim procesima 20. veka (Serbia and Modernization Changes of the $20^{\text {th }}$ century), Beograd: Institut za noviju istoriju Srbije. 
Vučo, Nikola (1955), Položaj seljaštva I: Eksproprijacija žemlje u XIX veku (The situation of farmers: Land expropriation in the $19^{\text {th }}$ century), Belgrade, 1955. 
Annex 1. Respectability and subsistence baskets, and wages, 1862-1910 (in nominal dinars)

\begin{tabular}{|c|c|c|c|c|}
\hline \multirow[b]{2}{*}{ Year } & \multirow[b]{2}{*}{$\begin{array}{l}\text { Cost of the } \\
\text { respectability } \\
\text { basket (in dinars, } \\
\text { per annum) }\end{array}$} & \multirow[b]{2}{*}{$\begin{array}{l}\text { Cost of the } \\
\text { subsistence } \\
\text { basket (in dinars, } \\
\text { per annum) }\end{array}$} & \multicolumn{2}{|c|}{$\begin{array}{c}\text { Wages without employer-provided food } \\
\text { and drinks (in dinars, per day; annual } \\
\text { average) }\end{array}$} \\
\hline & & & $\begin{array}{l}\text { Ordinary (unskilled) } \\
\text { worker }\end{array}$ & $\begin{array}{l}\text { Skilled } \\
\text { construction } \\
\text { worker }\end{array}$ \\
\hline 1862 & 104 & 38 & 1.11 & 1.87 \\
\hline 1863 & 95 & 35 & 0.97 & 1.59 \\
\hline 1864 & 107 & 42 & 1.00 & 1.58 \\
\hline 1865 & 100 & 35 & 1.04 & 1.71 \\
\hline 1866 & 96 & 36 & 1.03 & 1.85 \\
\hline 1867 & 107 & 43 & 1.16 & 2.05 \\
\hline 1868 & 111 & 40 & 1.03 & 2.11 \\
\hline 1869 & 100 & 33 & 1.47 & 2.23 \\
\hline 1870 & 107 & 37 & 1.56 & 2.38 \\
\hline 1871 & 113 & 43 & 1.58 & 2.41 \\
\hline 1872 & 126 & 49 & 1.49 & 2.42 \\
\hline 1873 & 137 & 49 & 1.45 & 2.28 \\
\hline 1874 & 131 & 50 & 1.40 & 2.22 \\
\hline 1875 & 123 & 44 & 1.45 & 2.14 \\
\hline 1876 & 111 & 37 & 1.42 & 2.09 \\
\hline 1877 & 126 & 43 & 1.38 & 2.18 \\
\hline 1878 & 128 & 45 & 1.40 & 2.23 \\
\hline 1879 & 102 & 38 & 1.44 & 2.30 \\
\hline 1880 & 114 & 51 & 1.47 & 2.65 \\
\hline 1881 & 109 & 39 & 1.69 & 2.82 \\
\hline 1882 & 117 & 45 & 1.72 & 2.88 \\
\hline 1883 & 107 & 37 & 2.05 & 3.17 \\
\hline 1884 & 132 & 45 & 1.95 & 3.21 \\
\hline 1885 & 109 & 38 & 1.61 & 2.64 \\
\hline 1886 & 106 & 37 & 1.58 & 2.78 \\
\hline 1887 & 106 & 39 & 1.39 & 2.68 \\
\hline 1888 & 100 & 38 & 1.28 & 2.60 \\
\hline 1889 & 104 & 38 & 1.19 & 2.38 \\
\hline 1890 & 110 & 39 & 1.15 & 2.33 \\
\hline 1891 & 129 & 44 & 1.32 & 2.63 \\
\hline 1892 & 125 & 38 & 1.42 & 2.65 \\
\hline 1893 & 122 & 34 & 1.52 & 2.80 \\
\hline 1894 & 132 & 37 & 1.46 & 2.84 \\
\hline 1895 & 129 & 39 & 1.28 & 2.72 \\
\hline 1896 & 114 & 32 & 1.19 & 2.55 \\
\hline 1897 & 127 & 38 & 1.21 & 2.61 \\
\hline
\end{tabular}




\begin{tabular}{|r|r|r|r|r|}
\hline 1898 & 143 & 41 & 1.13 & 2.57 \\
\hline 1899 & 132 & 33 & 1.15 & 2.56 \\
\hline 1900 & 130 & 34 & 1.22 & 2.50 \\
\hline 1901 & 138 & 36 & 1.19 & 2.50 \\
\hline 1902 & 144 & 40 & 1.21 & 2.50 \\
\hline 1903 & 146 & 42 & 1.24 & 2.59 \\
\hline 1904 & 149 & 47 & 1.24 & 2.60 \\
\hline 1905 & 151 & 50 & 1.23 & 2.71 \\
\hline 1906 & 146 & 41 & 1.29 & 2.83 \\
\hline 1907 & 152 & 42 & 1.30 & 2.95 \\
\hline 1908 & 158 & 46 & 1.33 & 3.03 \\
\hline 1909 & 170 & 47 & 1.40 & 3.19 \\
\hline 1910 & 166 & 43 & 1.61 & 3.39 \\
\hline Average & 123 & 41 & 1.35 & 2.50 \\
\hline
\end{tabular}

